\title{
FACTORS AFFECTING SOMATIC CELL COUNTS AND THEIR RELATIONS WITH MILK YIELD IN EGYPTIAN BUFFALO
}

Manal M. El-Bramony ${ }^{1}$, A. A. Nigm ${ }^{2}$, Kawthar A. Mourad ${ }^{1}$ and U. M. El-Saied ${ }^{1}$

1- Animal Production Research Institute, Ministry of Agriculture and Land Reclamation, Dokki, Giza, Egypt, 2- Department of Animal Production, Faculty of Agriculture, Cairo University, Giza, Egypt

\section{SUMMARY}

A total of 3189 records for each of daily milk yield (DMY) and $\log _{10}$ SCC (LSCC) in the first three parities for 364 Egyptian buffaloes raised at four experimental farms belonging to the Animal Production Research Institute, Egypt was used in this study. Data were collected at monthly intervals over the period from October 1999 to June 2004 to study non-genetic factors affecting DMY and LSCC, their trend along with the trajectory of DIM from 5 to $300 d$ and their phenotypic relationship in the first three parities.

The fixed model included herd-test date (HTD) effect, days in milk (DIM) (10 classes starting with 1 for DIM between 5 and $30 d$ and increased by 1 every 30 days along the trajectory up to 300d). Age at calving within each parity was analyzed as a covariate. Another trail was made using herd-year-season (HYS) effect instead of $H T D$. The results indicated that HTD had a highly significant effect $(P<0.001)$ on both DMY and LSCC in all parities. Moreover, using HTD effect increased the accuracy of the model when compared with HYS effect. DIM had a highly significant effect $(P<0.001)$ on DMY while it resulted a non-significant for LSCC in the first three parities. Age at calving had a significant effect on both DMY and LSCC in the second and third parities, while it had a non-significant effect on both traits in the first one. First parity had a different trend for both DMY and LSCC when compared to the second and third parities, which had similar trend. Curves for LSCC along the trajectory of DIM in the first three parities of Egyptian Buffalo shaped like an inverted milk production curves.

Keywords: Somatic Cell Count, Milk Yield, Egyptian buffalo

Abbreviation key: DMY = daily milk yield, $L S C C=\log _{10}$ Somatic cell count, DIM = days in milk, $H T D=$ herd-test date.

\section{INTRODUCTION}

In Egypt, buffaloes are considered the main dairy animals. They contribute about $60 \%$ of the national milk production. Mastitis is one of the most common and costly diseases in dairy farms worldwide; approximately $70-80 \%$ of losses suffered are due to sub clinical mastitis (Reneau and Packard, 1991). Moreover to milk losses, the disease results in changes in levels of specific milk components and therefore the overall milk quality is reduced (Eberhart et al., 1987; Kitchen, 1981; Harmon, 1994

Issued by The Egyptian Society of Animal Production 
and Cerón-Muñoz et al., 2002). Hence, reducing mastitis incidence is important for economical, environmental and welfare reasons.

Somatic cell count in milk has been accepted as the international standard for mastitis diagnosis by the International Dairy Federation (IDF Standard 148A, 1995). It has a high genetic correlation with mastitis, higher heritability than for mastitis, and relatively easy to be recorded compared to direct recording of mastitis. Therefore, SCC has been included in the national breeding programs of several countries since more than 10 years (International Bull Evaluation Service, 1996). In Egypt, where there is lack of national database on disease resistance, such as mastitis, SCC becomes very important as a tool for reducing mastitis incidence.

The objectives of this study were to study non-genetic factors affecting daily milk yield (DMY) and $\log _{10}$ SCC (LSCC), investigate their trend along the trajectory of days in milk (DIM) from 5 to $300 \mathrm{~d}$ and their phenotypic relationship in the first three parities of Egyptian buffalo.

\section{MATERIALS AND METHODS}

Animals and Management:

Data used in this study were collected at monthly intervals over the period from October, 1999 through June, 2004 from four experimental research herds belonging to the Animal Production Research Institute (APRI), Ministry of Agriculture and Land Reclamation, Egypt. Buffaloes were kept under semi-open sheds. Animals grazed Berseem (Trifolium alexandrium), when available, in addition to rice straw and different amounts of intergraded concentrate feed mixtures. The ration was offered twice daily and clean water was available all time. Buffaloes were handmilked twice a day at 7 a.m. and 4 p.m. throughout the lactation period in Gemiza and Mahalet Mossa farms while machine milking was practiced in Nattaf Gedeed and Nattaf Kadeem farms.

\section{Data:}

A total of 3189 test day records of milk yield and SCC (thousands/ml) of buffaloes in the first three parities were collected. There were 139, 198 and 174 buffalo cows with 878, 1242 and 1069 test day record for the first three parities, respectively.

Data included TD records between the $5^{\text {th }}$ and $300^{\text {th }}$ DIM. Buffaloes with less than 4 TD records /lactation were excluded from the data to insure better fitting of the lactation curve. Information after the $10^{\text {th }} \mathrm{TD}$ records was discarded from data file. After editing, the percentage of $82 \%$ of TDR's were kept in the file. Ten DIM classes were defined. The first class included test days between 5 and 30 DIM and all the subsequent tests were of $30 \mathrm{~d}$ interval up to 300 DIM. Table 1 presents average DIM (SD) for each DIM class for the first three parities. Age at calving ranged from 25 to $62 \mathrm{mo}$ for $1^{\text {st }}$ parity; from 39 to $99 \mathrm{mo}$ for $2^{\text {nd }}$ parity and from 49 to $125 \mathrm{mo}$ for $3^{\text {rd }}$ one. Average age at calving (SD) recorded 37.1 (6.3), $53.9(9.2)$ and $68.0(9.2)$ for the first three parities, respectively. 
Table 1. Average DIM (SD) for each DIM class for the first three parities

\begin{tabular}{|c|c|c|c|c|c|c|}
\hline \multirow{2}{*}{$\begin{array}{l}\text { DIM } \\
\text { class }\end{array}$} & \multicolumn{2}{|c|}{$1^{\text {st }}$ parity } & \multicolumn{2}{|c|}{$2^{\text {nd }}$ parity } & \multicolumn{2}{|c|}{$3^{\text {rd }}$ parity } \\
\hline & $\bar{X}$ & SD & $\bar{X}$ & SD & $\bar{X}$ & SD \\
\hline 1 & 18.6 & 7.0 & 18.2 & 7.8 & 17.9 & 7.9 \\
\hline 2 & 45.5 & 8.4 & 45.8 & 8.5 & 46.3 & 8.6 \\
\hline 3 & 75.5 & 8.4 & 75.5 & 8.5 & 74.7 & 8.2 \\
\hline 4 & 106.0 & 9.0 & 106.5 & 8.8 & 105.2 & 8.7 \\
\hline 5 & 135.7 & 8.5 & 136.2 & 8.5 & 134.8 & 8.1 \\
\hline 6 & 164.8 & 8.3 & 165.5 & 9.0 & 163.6 & 8.2 \\
\hline 7 & 195.0 & 8.8 & 195.9 & 8.5 & 193.1 & 9.0 \\
\hline 8 & 225.1 & 8.4 & 225.8 & 8.4 & 223.1 & 8.9 \\
\hline 9 & 245.2 & 8.6 & 252.9 & 8.9 & 251.0 & 7.6 \\
\hline 10 & 283.5 & 8.5 & 280.8 & 9.3 & 277.3 & 6.1 \\
\hline
\end{tabular}

DIM: days in milk

Individual SCC records for each test day were transformed to $\log _{10} \mathrm{SCC}$ to meet the characteristics needed by hypothesis testing (Ali and Shook, 1980). SCC was measured alternatively following a monthly a.m.-p.m. recording scheme by automated method of infrared absorption spectrophotometry (Milk-o-Scan; Foss Electric, Hillerфd, Denmark) at the Dairy Services Unit, which belonging to the Animal Production Research Institute, Sakha, Kafr El-Sheikh Governorate.

\section{Statistical Model:}

Fixed effects were analyzed applying the general linear model (GLM) procedure of SAS (SAS, 1996). The following statistical model was applied separately for each of the first three parities:

$\mathrm{Y}_{\mathrm{ijk}}=\mu+\mathrm{HTD}_{\mathrm{i}}+\mathrm{DIM}_{\mathrm{j}}+\mathrm{b}(\mathrm{A})+\mathrm{e}_{\mathrm{ijk}}$

where:

$\mathrm{Y}_{\mathrm{ijk}}$ is the $\mathrm{k}^{\text {th }}$ record of DMY or LSCC taken in the ${ }_{\mathrm{i}}^{\text {th }}$ herd-test date and belonging to the $\mathrm{j}^{\text {th }}$ DIM class;

$\mu$ is the overall mean;

$\mathrm{HTD}_{i}$ is the fixed effect of the ${ }_{i}{ }^{\text {th }}$ herd-test date, $\mathrm{i}=(146,178$ and, 169 for the first three parities, respectively;

DIM $_{\mathrm{j}}$ is the fixed effect of the $\mathrm{j}^{\text {th }}$ days in milk where $\mathrm{j}=10$ classes starting with $\mathrm{j}=1$ for DIM between 5 and 30d and increased by 1 every 30 days thereafter along the trajectory up to $300 \mathrm{~d}$;

$\mathrm{b}(\mathrm{A})$ is the effect of the a covariable age at calving on the studied traits and $\mathrm{e}_{\mathrm{ijk}}$ is the random residual term associated with each observation.

\section{RESULTS AND DISCUSSION}

Arithmetic means for DMY, SCC (thousands/milliliter) and LSCC and their standard deviations for the first three parities are shown in Table 2. 
Table 2. Arithmetic means (SD) for variables studied in the first three parities

\begin{tabular}{|c|c|c|c|c|c|c|}
\hline \multirow[t]{2}{*}{ Variable } & \multicolumn{2}{|c|}{$1^{\text {st }}$ parity } & \multicolumn{2}{|c|}{$2^{\text {nd }}$ parity } & \multicolumn{2}{|c|}{$3^{\text {rd }}$ parity } \\
\hline & $\bar{X}$ & SD & $\bar{X}$ & SD & $\bar{X}$ & SD \\
\hline DMY, Kg & 6.55 & $(2.68)$ & 7.77 & $(3.15)$ & 8.00 & $(3.11)$ \\
\hline LSCC & 4.74 & $(0.53)$ & 4.80 & $(0.52)$ & 4.83 & $(0.53)$ \\
\hline SCC: thousands/milliliter & 140.6 & $(405)$ & 143.4 & $(275)$ & 153.7 & $(272)$ \\
\hline
\end{tabular}

DMY: Daily milk yield; LSCC: $\log _{10}$ SCC; SCC: Somatic cell count.

Daily milk yield (DMY, Kg) increased with parity order. The same trend was reported by Badran et al. (2002) for Egyptian buffalo. LSCC means were higher than that obtained by Cerón-Muñoz et al. (2002) for Murrah buffaloes (1.13) and are comparable with means (4.0 to 5.4) estimated for dairy cows (Amin et al., 2000; Haile-Mariam et al., 2001 and 2003; Mrode and Swanson, 2003 and Ødegård et al., 2003). Although solutions for parity were not estimated in this study, it was noted that LSCC increased with parity. Generally, the increase in SCC with parity (age) is attributed to the fact that older cows have a greater opportunity for exposure to mastitis causing pathogens than younger cows (Reneau, 1986 and Detilleux et al., 1997). The results of the analysis of variance of the non-genetic effects on daily milk yield and LSCC in the first three parities are presented in Table 3.

Table 3. Analysis of variance for daily milk yield (DMY, Kg) and $\log _{10}$ SCC (LSCC) in the first three parities

\begin{tabular}{|c|c|c|c|c|c|c|c|c|c|}
\hline \multirow{2}{*}{$\begin{array}{l}\text { Source } \\
\text { variance }\end{array}$} & \multirow[t]{2}{*}{ d.f } & \multicolumn{2}{|c|}{$1^{\text {st }}$ parity } & \multirow[t]{2}{*}{ d.f } & \multicolumn{2}{|c|}{$2^{\text {nd }}$ parity } & \multirow[t]{2}{*}{ d.f } & \multicolumn{2}{|c|}{$3^{\text {rd }}$ parity } \\
\hline & & $\overline{D M Y}$ & LSCC & & DMY & LSCC & & DMY & $\overline{\mathrm{LSCC}}$ \\
\hline HTD & 145 & $* * *$ & $* * *$ & 177 & $* * *$ & $* * *$ & 168 & $* * *$ & $* * *$ \\
\hline DIM Classes & 9 & $* *$ & NS & 9 & $* * *$ & NS & 9 & $* * *$ & NS \\
\hline $\begin{array}{l}\text { Reg. On age } \\
\text { at calving }\end{array}$ & 1 & NS & NS & 1 & $* * *$ & $*$ & 1 & $* *$ & $* *$ \\
\hline
\end{tabular}

HTD: herd-test date; DIM: days in milk.

*Significant $(P<0.05) ; * *(P<0.01) ; * * *(P<0.001)$; NS= Non significant.

\section{Herd-test date:}

Both DMY and LSCC were significantly affected $(\mathrm{P}<0.001)$ by HTD across the first three parities. This is in agreement with (El-Saeid, 1998 and Nigm et al., 2003) for dairy sheep and dairy cows, respectively. HTD in test-day models permits a relatively good explanation of environmental variation because it is associated with the specific events in the day of test for each herd. Moreover, accuracy $\left(\mathrm{R}^{2}\right)$ increased by 26 and $68 \%$, respectively for DMY and LSCC when using HTD in the same model instead of herd-year-season (HYS) effect. Similar results were given by Nigm et al. (2003).

\section{Age at calving:}

Age at calving had a significant effect $(\mathrm{P}<0.05)$ on both DMY and LSCC in the second and third parities (Table 3), while it had no effect on both traits in the first parity. Age at calving within parity for SCC; have been investigated by many authors (Kenndy et al., 1982; Boethcher et al., 1992; Schutz et al., 1995; Amin et al., 2000 
and Haile-Mariam et al., 2001). The authors found that SCC tended to increase with advancing order of lactation and age at calving within parity in a linear fashion. This means that young cows tended to have lower SCC than the multiparous cows. Boettcher et al. (1992) added that young cows tended to have highest SCC in short lactations, whereas older cows had highest SCC in complete lactation. Variation in SCC due to the effect of calving age within first parity was higher than within other parities (Amin et al., 2000). Effects like the dilution by milk volume or stage of lactation may also give reasonable interpretation for the increase of SCC with age at test.

\section{Days in milk (DIM):}

Daily milk yield was significantly affected $(\mathrm{P}<0.001)$ by DIM in the first three parities (Table 3). No previous results were available for buffalo. However, the results are in agreement with the findings of El-Saeid et al. (1998) for Churra dairy sheep and Nigm et al. (2003) for Holstein cattle. The effect of DIM reflects accurately the effect of lactation stage at the time on test milk yield. Table 4 presents least squares means for daily milk yield (DMY) in the first three parities.

Table 4. Least squares means $( \pm \mathrm{SE})$ for daily milk yield $(\mathrm{DMY})$ in the first three parities

\begin{tabular}{|c|c|c|c|c|c|c|c|c|c|}
\hline \multirow{2}{*}{$\begin{array}{l}\text { DIM } \\
\text { class }\end{array}$} & \multicolumn{3}{|c|}{$1^{\text {st }}$ parity } & \multicolumn{3}{|c|}{$2^{\text {nd }}$ parity } & \multicolumn{3}{|c|}{$3^{\text {rd }}$ parity } \\
\hline & $\begin{array}{c}\text { No of } \\
\text { records }\end{array}$ & DMY & SE & $\begin{array}{c}\text { No of } \\
\text { records }\end{array}$ & DMY & SE & $\begin{array}{c}\text { No of } \\
\text { records }\end{array}$ & DMY & SE \\
\hline 1 & 136 & $6.09^{\mathrm{ab}}$ & 0.20 & 194 & $7.76^{\mathrm{abc}}$ & 0.18 & 168 & $8.60^{\mathrm{ab}}$ & 0.19 \\
\hline 2 & 138 & $6.76^{\mathrm{a}}$ & 0.19 & 196 & $8.43^{\mathrm{a}}$ & 0.18 & 174 & $9.10^{\mathrm{a}}$ & 0.19 \\
\hline 3 & 138 & $6.95^{\mathrm{a}}$ & 0.19 & 197 & $8.05^{\mathrm{ab}}$ & 0.18 & 174 & $8.75^{\mathrm{ab}}$ & 0.18 \\
\hline 4 & 137 & $6.85^{\mathrm{a}}$ & 0.19 & 198 & $7.63^{\mathrm{abc}}$ & 0.18 & 173 & $8.02^{a b c}$ & 0.18 \\
\hline 5 & 108 & $6.40^{\mathrm{ab}}$ & 0.22 & 160 & $7.2^{\mathrm{bcd}}$ & 0.20 & 146 & $7.42^{\text {cde }}$ & 0.20 \\
\hline 6 & 87 & $6.41^{\mathrm{ab}}$ & 0.24 & 123 & $6.71^{\text {cde }}$ & 0.23 & 114 & $6.93^{\mathrm{cd}}$ & 0.23 \\
\hline 7 & 59 & $6.60^{\mathrm{a}}$ & 0.29 & 87 & $6.22^{\text {de }}$ & 0.27 & 69 & $6.60^{\mathrm{cd}}$ & 0.29 \\
\hline 8 & 40 & $6.26^{\mathrm{a}}$ & 0.35 & 51 & $5.53^{\mathrm{e}}$ & 0.34 & 32 & $6.17^{\mathrm{d}}$ & 0.42 \\
\hline 9 & 22 & $5.33^{\mathrm{bc}}$ & 0.46 & 27 & $5.94^{\mathrm{e}}$ & 0.46 & 15 & $5.95^{\mathrm{cd}}$ & 0.63 \\
\hline 10 & 13 & $5.70^{c}$ & 0.59 & 9 & $6.45^{\text {cde }}$ & 0.79 & 4 & $5.57^{\mathrm{cd}}$ & 1.16 \\
\hline
\end{tabular}

DIM: days in milk; Means within a column with different superscripts differ significantly $(P<0.05)$.

Results in table 4 show that DMY of the first parity increased until the third DIM class followed by a slight insignificant decrease till the fourth one and then decreased significantly until the ninth class. Similar trend was reported by Ibrahim (1995) of Egyptian buffaloes and Haile-Mariam et al. (2001) for Australian cows. First parity had a lower daily milk yield (DMY) than those for the second and third parities (Figure 1). Second and third parities have similar trend. DMY increased significantly $(\mathrm{P}<0.05)$ till the second DIM class and then decreased significantly to the end of lactation stage.

Estimates of all parities were in close agreement with those reported by CerónMuñoz et al. (2002) for Murrah buffaloes in Brazil. Similar trends were also reported for Egyptian buffalo by Samak et al. (1988), Mansour et al. (1993) and Badran et al. (2002). 


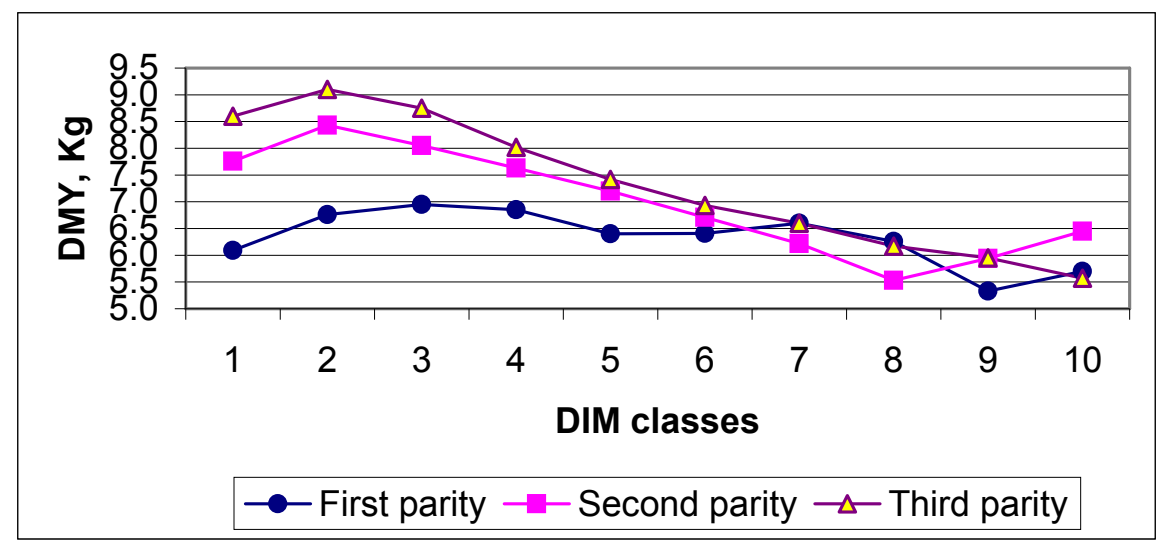

Figure 1. Change with DIM classes for DMY, $\mathrm{kg}$ in the first three parities

On the other hand, DIM effect was non-significant on LSCC in the three parities. Means are tabulated in Table 5 and their trend is graphically represented in Figure 2. First parity had a different trend than second and third. LSCC decreased reaching its minimum level at the third month. Then the curve fluctuated to the ninth month and then sharply decreased in the tenth one. These results are in good agreement with those reported by Schepers et al. (1997) and Cerón-Muñoz et al. (2002).

Again, and as for DMY, LSCC had similar trend in the second and the third parities when compared with the $1^{\text {st }}$ one. In all cases, LSCC tended to increase rapidly toward the end the trajectory. The similarity in the lactation curve for $2^{\text {nd }}$ and $3^{\text {rd }}$ lactations compared with the $1^{\text {st }}$ lactation in the current study is in agreement with the results reported by Zhang et al. (1994); Reents et al. (1995) and Haile-Mariam et al. (2001) for dairy cows.

Table 5. Least squares means $( \pm \mathrm{SE})$ for $\log _{10}$ SCC (LSCC) in the first three parities

\begin{tabular}{|c|c|c|c|c|c|c|c|c|c|}
\hline \multirow{2}{*}{$\begin{array}{l}\text { DIM } \\
\text { class }\end{array}$} & \multicolumn{3}{|c|}{$1^{\text {st }}$ parity } & \multicolumn{3}{|c|}{$2^{\text {nd }}$ parity } & \multicolumn{3}{|c|}{$3^{\text {rd }}$ parity } \\
\hline & $\begin{array}{c}\text { No of } \\
\text { records }\end{array}$ & LSCC & SE & $\begin{array}{c}\text { No of } \\
\text { records }\end{array}$ & LSCC & SE & $\begin{array}{c}\text { No of } \\
\text { records }\end{array}$ & LSCC & SE \\
\hline 1 & 136 & 4.85 & 0.05 & 194 & 4.80 & 0.04 & 168 & 4.84 & 0.04 \\
\hline 2 & 138 & 4.74 & 0.05 & 196 & 4.82 & 0.04 & 174 & 4.82 & 0.04 \\
\hline 3 & 138 & 4.68 & 0.05 & 197 & 4.80 & 0.04 & 174 & 4.79 & 0.04 \\
\hline 4 & 137 & 4.80 & 0.05 & 198 & 4.84 & 0.04 & 173 & 4.84 & 0.04 \\
\hline 5 & 108 & 4.73 & 0.05 & 160 & 4.80 & 0.04 & 146 & 4.81 & 0.04 \\
\hline 6 & 87 & 4.81 & 0.06 & 123 & 4.82 & 0.05 & 114 & 4.81 & 0.05 \\
\hline 7 & 59 & 4.70 & 0.07 & 87 & 4.80 & 0.06 & 69 & 4.89 & 0.06 \\
\hline 8 & 40 & 4.85 & 0.09 & 51 & 4.79 & 0.07 & 32 & 4.74 & 0.09 \\
\hline 9 & 22 & 4.95 & 0.11 & 27 & 4.71 & 0.10 & 15 & 4.83 & 0.14 \\
\hline 10 & 13 & 4.72 & 0.14 & 9 & 5.26 & 0.17 & 4 & 5.10 & 0.26 \\
\hline
\end{tabular}

DIM: days in milk 


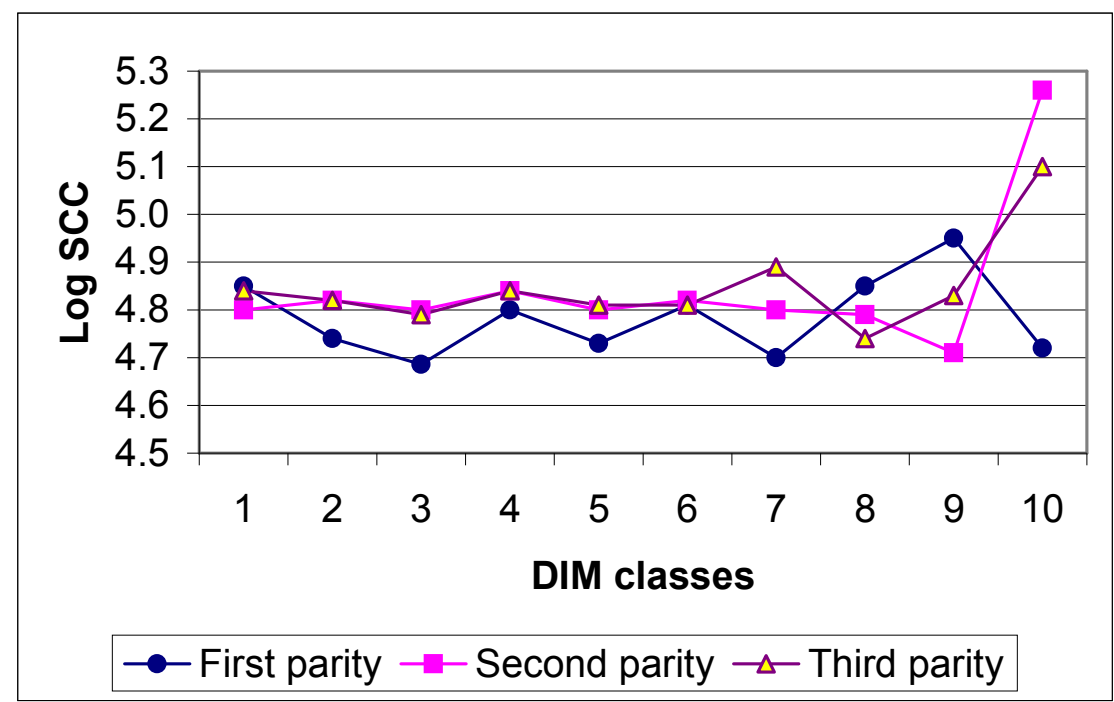

Figure 2. Change with DIM classes for LSCC in the first three parities

Cerón-Muñoz et al. (2002) described that all parities had a lower (first through fifth) $\log _{2}$ SCC in the second month of lactation and increased thereafter up to the ninth month for Murrah buffaloes.

In dairy cows, Heuven et al. (1988) stated that the variation in SCC in $1^{\text {st }}$ parity is mainly due to normal variation whereas variation in $2^{\text {nd }}$ and latter parities was largely due to incidental factors such as mastitis. However, Haile-Mariam et al. (2001) found that later in the $1^{\text {st }}$ lactation and in later lactations, high or increased SCC are largely due to responses to infection which result in more stable elevation and the large temporary environmental effects in early lactation. This also agrees with the result of Detilleux et al. (1997) who suggested that the risk of intramammary infection from environmental pathogens, which cause a small increase in SCC, is high at the end of lactation.

Figure 3 presents the phenotypic relationship between means for DMY and LSCC along with DIM in the third parity. The figure demonstrates clearly that the curve of LSCC along DIM trajectory is shaped like an inverted milk production curve. This is also the case in the first two parities. Similar trend in cows was reported by Weller et al. (1992), Zhang et al. (1994), Reents et al. (1995), Haile-Mariam et al. (2001) and Cerón- Muñoz et al. (2002). 


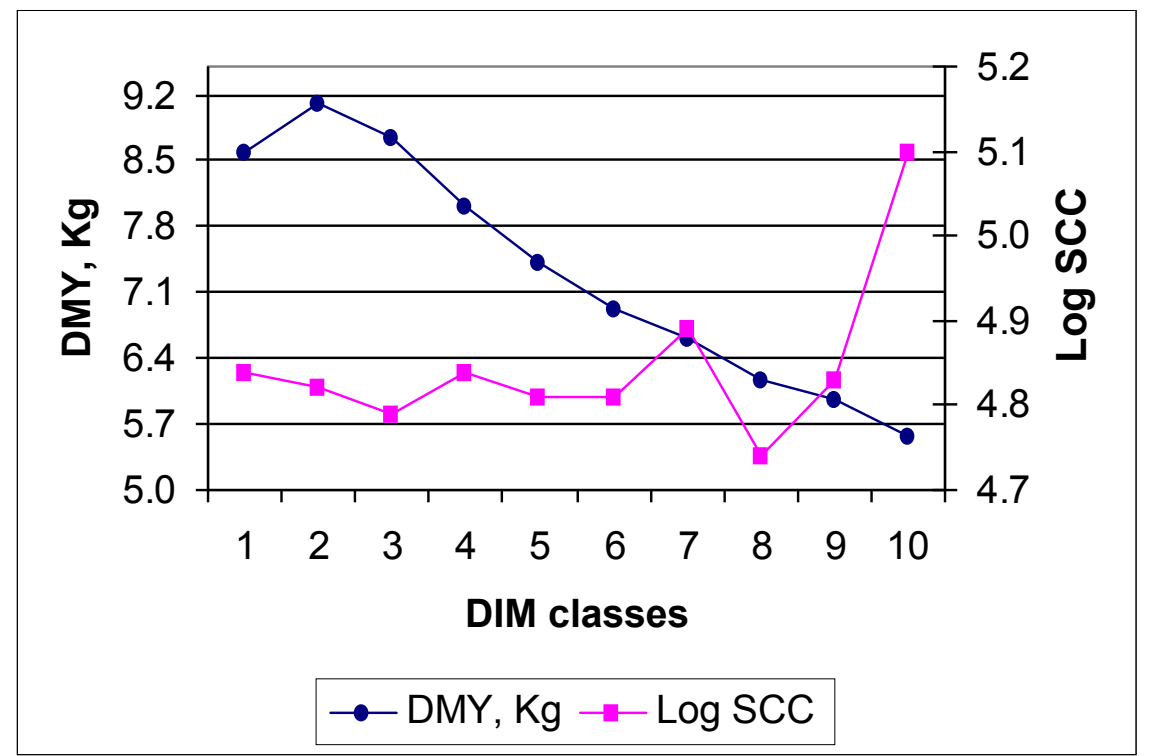

Figure 3. Trends for DMY, kg and LSCC along with DIM classes in the third parity for Egyptian buffalo

\section{CONCLUSIONS}

The results indicated that HTD is an important effect in models analyzing test day records for DMY and LSCC. First parity had a different trend for both DMY and LSCC than second and third parities, which had similar trends. Curves for LSCC along the trajectory of DIM in the first three parities of Egyptian buffalo shaped like an inverted milk production curves.

\section{REFERENCES}

Ali, A. K. A. and G. E. Shook. 1980, An optimum transformation for somatic cell concentration in milk. J. Dairy Sci. 63:487-490.

Amin, A. A., S. Mokhtar and T. Gere, 2000. Test-day and whole lactation repeatability for somatic cell count and some milk production traits of Holstein Friesian cows in Hungary. Egyptian J. Anim. Prod.37 (2): 85-97.

Badran, A. E., A. El-Barbary A. E. Mahdy and G. M. Assar, 2002. Genetic and nongenetic factors affecting the lifetime production traits in Egyptian buffaloes. Buffalo J. 2:235-241.

Boettcher, P. J., L. B. Hansen P. M. VanRaden and C. A. Ernst, 1992. Genetic evaluation of Holstein bulls for somatic cells in milk of daughters. J. Dairy Sci. 75:1127-1137. 
Cerón-Muñoz, M., H. Tonhati J. Duarte J. Oliveira M. Muñoz-Berrocal and H. Jurado-Gámez, 2002. Factors affecting somatic cell counts and their relations with milk and milk constituent yield in Buffaloes. J. Dairy Sci. 85: 2885-2889.

Detilleux, J., P. Leroy and D. Volckaert, 1997. Alternative use of somatic cell counts in genetic selection for mastitis resistance. Proc. Intl. Workshop on GIFT in Cattle, Health, Uppsala, Sweden. Interbull Bull. 15:34-44.

Eberhart, R. J., R. J. Harmon D. E. Jasper R. P. Natzke S. C. Nickerson J. K. Reneau E. H. Row K. L. Smith and S. B. Spencer,1987. Current concepts of bovine mastitis. 3rd ed. Natl. Mastitis Counc., Inc., Arlington, VA.

El-Saied, U. M., J. A. Carriedo L. F. de la Fuente and F. San Primitivo, 1998. Genetic and environmental estimations for test-day and standardized milk yield of dairy sheep. Small Ruminant Res. 27:209-215.

Haile-Mariam, M., M. E. Goddard and P.J. Bowman, 2001. Estimates of genetic parameters for daily somatic cell count of Australian daily cattle. J. Dairy Sci. 84:1255-1264.

Haile-Mariam, M., P. J. Bowman M. E. Goddard, 2003. Genetic and environmental relationship among calving interval, survival, persistency of milk yield and somatic cell count in dairy cattle. J. Dairy Sci 80: 189-200.

Harmon, R. J, 1994. Physiology of mastitis and factors affecting somatic cell counts. Symposium: Mastitis and genetic evaluation for somatic cell count. J. Dairy Sci. 77:2103-2112.

Heuven, H. C. M., H. Bovenhuis and R. D. Politiek, 1988. Inheritance of somatic cell count and its genetic relationship with milk yield in different parities. Livest. Prod. Sci. 18:115-127.

Ibrahim, M. A. M., 1995. The used of gamma-type function in describing the lactation curve of Egyptian buffaloes. Egyptian J. Anim. Prod.32:113.

International Bull Evaluation Service, 1996. Sire evaluation procedures for nondairy-production and growth \& beef production traits practiced in various countries 1996. INTERBULL Bulletin No. 13. Int. Bull Eval. Serv., Uppsala, Sweden.

International IDF Standard 148A, 1995. Milk Enumeration of Somatic Cells. International Dairy Federation, Brussels, Belgium.

Kennedy, B. W., M. S. Sethar A. K. W. Tong J. E. Moxley and B. R. Downey, 1982. Environmental factors influencing test-day somatic cell counts in Holsteins. J. Dairy Sci. 65:275-281.

Kitchen, B. J., 1981. Review of progress of dairy science: bovine mastitis: milk compositional changes and related diagnostic tests. J. Dairy Res. 48:167-188.

Mansour, H., I. A. Soliman and G. A. Abd El-Haafiz, 1993. Factors affecting lactation curve of buffalo in upper Egypt. Proceeding of the international Symp. on prospects of buffalo production in the Mediterraneana and middle East. Cairo, Egypt Nov., 9-12 1992. EAAP publications. 62:234-237.

Mrode, R. A. and G. J. T. Swanson, 2003. Estimation of genetic parameters for somatic cell count in the first three lactations using random regression. Livest. Prod. Sci. 79: 239-247.

Nigm, A. A., S. A. Attallah S. Abou-Bakr and R. R. Sadek, 2003. Study on applying test day model for genetic evaluation of milk yield of Holstein cattle in Egypt. Egyptian J. Anim. Prod.40 (2): 89-98. 
Ødegård, J., G. Klemetsdal and B. Heringstad, 2003. Variance components and genetic trend for somatic cell count in Norwegian Cattle. Livest. Prod. Sci. 79: 135-144.

Reents, R., J. Jamrozik L. R. Schaeffer and J. C. M. Dekkers, 1995. Estimation of genetic parameters for test day records of somatic cell score. J. Dairy Sci. 78: 2847-2857.

Reneau, J. K., 1986. Effective use of dairy herd improvement somatic cell counts in mastitis control. J. Dairy Sci. 69:1708-1720.

Reneau, J. K., and V. S. Packard, 1991. Monitoring mastitis, milk quality and economic losses in dairy fields. Dairy Food Environ. Sanit. 11:4-11.

Samak, M. A., G. A. Hassan A. Hassan and N. Yassen. 1988. The lactation curve and performance of the Egyptian buffalo. Alex. Sci. Exch. 9:83-96.

SAS/STAT® User's Guide, Release 6.12. Edition. 1996. SAS Inst., Inc., Cary, NC.

Schepers, A. J., T. J. G. M. Lam Y. H. Schukken J. B. M. Wilmink and W. J. A. Hanekamp, 1997. Estimation of variance components for somatic cell counts to determine thresholds for uninfected quarters. J. Dairy Sci. 80:1833-1840.

Schutz, M. M., P. M. Van Raden G. R. Wiggans and H. D. Norman, 1995. Standardization of lactation means of somatic cell scores for calculation of genetic evaluations. J. Dairy Sci.78:1843-1854.

Weller, J. I., A. Saran and Y. Zeliger, 1992. Genetic and environmental relationships among somatic cell count, bacterial infection, and clinical mastitis. J. Dairy Sci. 75:2532-2540.

Zhang, W. C., J. C. M. Dekkers G. Banos and E. B. Burnside, 1994. Adjustment factors and genetic evaluation for somatic cell score and relationships with other traits of Canadian Holsteins. J. Dairy Sci. 77:659-665. 
العوامل المؤثرة على تعداد الخلايا الجسدية وعلاقتها بإنتاج اللبن في الجاموس المصري منال محمد البرمونى'، على عطيه نجم'، كوثر عبد المنعم مراد'، أ سامة محمد السعيد'

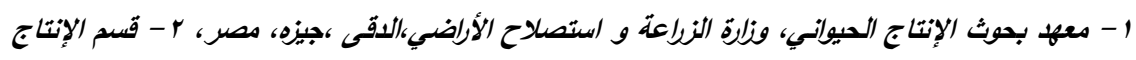
الحيوانسي كلية الزراعة، جامعة القا هرة، جيزه، مصر.

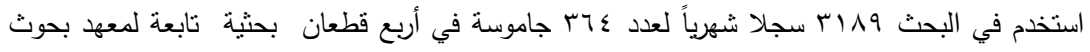

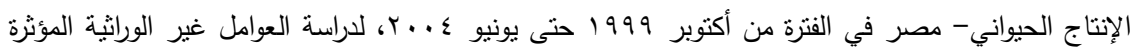

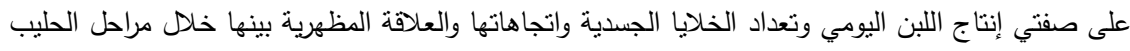

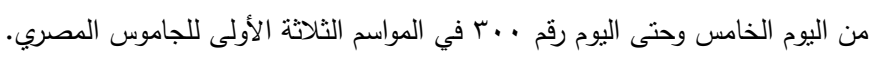

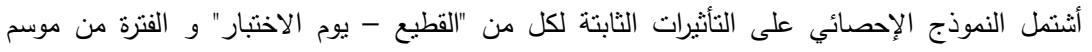

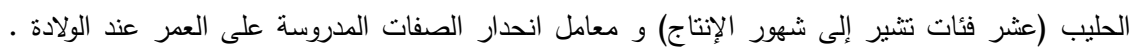

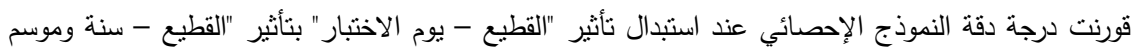

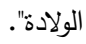

أظهرت النتائج نأثيراً عالي المعنوية "للقطيع - بوم الاختبار" على صفتي إنتاج اللبن اليومي و الخلايا.

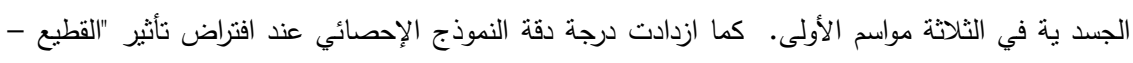

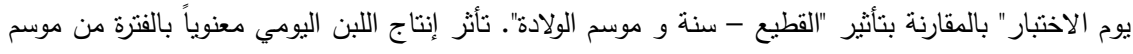

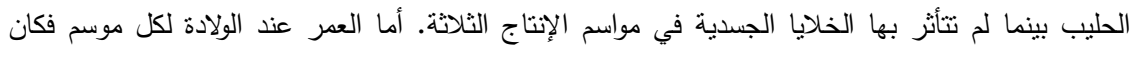

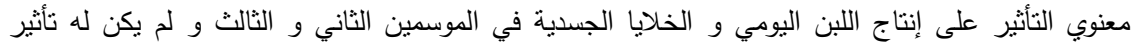

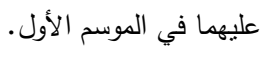
تثابه نمط إنتاج اللبن لمنحنى الحليب للموسمين الثاني و الثالث، و كذلك الحال لتعداد الخالايا الجسدية

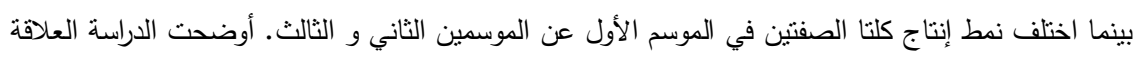

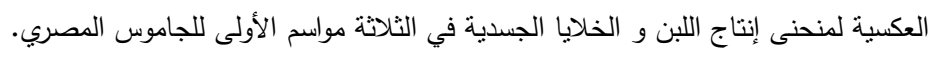

